\title{
Platelet Glycoprotein V
}

National Cancer Institute

\section{Source}

National Cancer Institute. Platelet Glycoprotein V. NCI Thesaurus. Code C126557.

Platelet glycoprotein V (560 aa, $61 \mathrm{kDa}$ ) is encoded by the human GP5 gene. This protein is involved in von Willebrand factor binding. 